\title{
Effects of seabird nesting colonies on algae and aquatic invertebrates in coastal waters
}

\author{
Gundula S. Kolb*, Janna Ekholm, Peter A. Hambäck \\ Department of Botany, University of Stockholm, 10691 Stockholm, Sweden
}

\begin{abstract}
Seabirds concentrate nutrients from large marine areas on their nesting islands. The high nutrient load may cause runoff into surrounding waters and affect marine communities in similar ways to those reported from marine fertilization experiments. In order to test if cormorant colonies affect algae and invertebrates in surrounding coastal waters, we collected Fucus vesiculosus fronds, its epiphytic algae, and associated invertebrate fauna near abandoned and active cormorant nesting islands as well as reference islands without nesting cormorants in the Stockholm archipelago in the northern Baltic Sea, Sweden. First, we showed, with $\delta^{15} \mathrm{~N}$ analyses, that ornithogenic nitrogen provided a significant nitrogen source for algae and invertebrate consumers near islands with high nest density. Second, the nitrogen and phosphorus content of algae near active cormorant islands with high nest density was elevated, and epiphytic algae increased relative to F. vesiculosus. Third, 3 of 5 invertebrate taxa (Jaera albifrons, Gammarus spp., and Chironomidae) showed increased biomasses near islands with high nest density; but, contrary to former fertilization studies, only $J$. albifrons increased in abundance compared to reference islands. We conclude that runoff from seabird colonies has a profound effect on primary producers and some consumers in the surrounding water, but only if the colonies exceed a certain nest density. Thus, seabirds not only affect marine communities via top-town forces as commonly assumed, but also via bottom-up forces by concentrating nutrients around their nesting islands. Consequently, seabird islands can be seen as natural fertilization experiments and give important insights to the effects of eutrophication of marine systems.
\end{abstract}

KEY WORDS: Nitrogen · Stable isotopes $\cdot$ Bottom-up $\cdot$ Eutrophication $\cdot$ Baltic Sea $\cdot$ Cormorants

\section{INTRODUCTION}

Seabirds play an important role in marine environments, as predators on marine animals and by concentrating marine nutrients on their nesting islands (Hutchinson 1950, Lindeboom 1984). The high nutrient load on nesting islands may cause runoff into surrounding waters and affect marine communities in similar ways to anthropogenic eutrophication (Golovkin \& Garkavaya 1975, Staunton Smith \& Johnson 1995). Eutrophication of freshwater systems and coastal waters is a serious global problem threatening services that these aquatic resources provide (Postel \& Carpenter 1997, Smith 2003, Rönnberg \& Bonsdorff 2004). Algae generally respond to increased nitrogen $(\mathrm{N})$ and phosphorus $(\mathrm{P})$ concentration with increased biomass and changed species composition, whereas consequences of eutrophication on marine consumers are less known and often difficult to study (Tilman 1982, Grover 1997, De Jonge et al. 2002, Smith 2003, Rönnberg \& Bonsdorff 2004). Seabird islands might provide suitable natural experiments to study responses by marine organisms to increased nutrient concentration (Wootton 1991).

The water columns of ponds, lakes, tide pools, and oceans near seabird colonies are often enriched in $\mathrm{N}$ $\left(\mathrm{NO}_{3}{ }^{-}, \mathrm{NO}_{2}{ }^{-}, \mathrm{NH}_{4}{ }^{+}, \mathrm{NH}_{3}\right)$ and $\mathrm{P}\left(\mathrm{PO}_{4}{ }^{-}\right)$(e.g. Golovkin \& Garkavaya 1975, Bosman et al. 1986, Bosman \& Hockey 1988, Keatley et al. 2009), and should produce strong positive responses of primary producers (Elser et al. 2007). Many studies also show that fast growing filamentous algae and invertebrate consumers respond 
with increasing productivity, biomass, and abundance to nutrient enrichments (Pedersen \& Borum 1996, Worm et al. 2000, Worm \& Sommer 2000, Kraufvelin et al. 2006, Korpinen et al. 2007, Kraufvelin 2007, Råberg \& Kautsky 2008). Similarly, algae and vascular plants near seabird colonies were shown to have increased abundances, growth rates, or nutrient contents (Golovkin 1967, Onuf et al. 1977, Bosman et al. 1986, Bosman \& Hockey 1988, but see Wootton 1991). These changes in the primary producers can affect aquatic consumers via bottom-up forces and both increase and decrease consumer abundance as shown for zooplankton (Zelickman \& Golovkin 1972), polychaetes (Bosman \& Hockey 1986), crustaceans (Wootton 1991, Palomo et al. 1999), chironomids (Michelutti et al. 2009), and fishes (Onuf et al.1977).

Previous studies on the effects of seabird colonies on adjusted marine ecosystems did not combine the power of stable isotope analyses for showing trophic links with data on biomass and abundance responses of algae and invertebrates. In the present study, we aimed to connect both types of data for one specific system by collecting Fucus vesiculosus (hereafter Fucus) fronds with their epiphytic algae and associated invertebrate fauna in coastal waters surrounding cormorant nesting islands (abandoned islands, active islands with low and high nest densities) and reference (i.e. non-cormorant) islands in the archipelago of Stockholm, Sweden. We focused on bottom-up effects and disregarded possible top-down forces from cormorants, through fish consumption, because cormorants usually forage in a rather large area $\left(1250 \mathrm{~km}^{2}\right)$ and thus might affect also reference islands (Paillisson et al. 2004, Engström 2001).

In order to investigate which algae and invertebrates utilize avian nitrogen, we first compared the $\delta^{15} \mathrm{~N}$ contents of Fucus, its epiphytic algae, and associated invertebrate taxa from the 3 cormorant island categories with the reference islands. We expected enriched $\delta^{15} \mathrm{~N}$ ratios of algae and invertebrates near cormorant islands. Second, we investigated indirectly if cormorants increase the nutrient availability in coastal waters around their nesting island by comparing the $\mathrm{P}$ content of algae and the $\mathrm{N}$ and $\mathrm{P}$ content of algae and associated invertebrates from the same set of islands. Third, we tested if the ratio of epiphytic algae to Fucus was increased near cormorant islands and expected, based on previous studies on nutrient enrichment effects in marine systems, increased epiphytic loads in the waters near cormorant islands (Worm et al. 2000, Råberg \& Kautsky 2008). Fourth, we investigated if aquatic invertebrates responded to the high nutrient loads around cormorant islands by comparing the abundance and biomass of invertebrate grazers and chironomids from the 3 cormorant island categories with reference islands. Based on previous studies - both nutrient enrichment studies in the Baltic Sea (Kotta et al. 2000, Kraufvelin 2007) and studies investigating the effects of seabirds on aquatic consumers (Bosman \& Hockey 1986, Palomo et al. 1999, Michelutti et al. 2009) - we expected increased invertebrate abundances and biomasses near cormorant islands.

\section{MATERIALS AND METHODS}

Study site and study species. The study was conducted in late July 2007 and 2008 in the Stockholm archipelago in the northern Baltic Sea, Sweden. The Baltic Sea is a large estuarine system with a narrow connection to the North Sea and no tides. Changes in water level are therefore mainly dependent on regional wind and atmospheric pressure conditions. Furthermore, the Baltic Sea has brackish water, and the salinity in the Stockholm archipelago is about $6 \mathrm{psu}$. The low salinity enables only a few marine and freshwater species to occur in the Baltic Sea. Eutrophication is one of the major environmental problems in the Baltic Sea, especially in coastal regions, and the main nitrogen sources are rivers and atmospheric deposition (Elmgren 2001, Voss et al. 2006). The yearly nitrogen deposition in the central Baltic Sea was estimated to be $617 \mathrm{mg} \mathrm{N} \mathrm{m}^{-2} \mathrm{yr}^{-1}$ and composed of $\sim 10 \%$ organic $\mathrm{N}$ and approximately equal amounts of ammonium and nitrate, with an average $\delta^{15} \mathrm{~N}=2.0 \%$ (Rolff et al. 2008). The yearly phosphorus deposition is much lower averaging $7.3 \mathrm{mg} \mathrm{N} \mathrm{m}^{-2} \mathrm{yr}^{-1}$, and consists of 20 to $40 \%$ organic P (Rolff et al. 2008).

Cormorants Phalacrocorax carbo recolonized the Stockholm archipelago in 1994, after hundreds of years of absence, increasing strongly in numbers until 2007 when the population size seemed to have stabilized at about 5200 breeding pairs (Staav 2008, 2009, 2010). From April to August, the cormorants nest in colonies, distributed over about 20 islands across the archipelago (Staav 2008). To illustrate the quantitative flow of nutrients on and around cormorant nesting islands, we used published data on the nutrient content of guano (Fig. 1). Cormorant guano is, as other seabird guano, highly enriched in $\mathrm{N}$ and $\mathrm{P}$, but the exact nutrient composition seems to differ between habitats (Marion et al. 1994, Osono et al. 2002). Dry cormorant guano from a French lake was reported to contain $3.3 \% \mathrm{~N}$ and $14.3 \%$ P (Marion et al. 1994), whereas the cormorant guano from a Japanese lake was estimated to contain $10.1 \% \mathrm{~N}$ and $9.2 \% \mathrm{P}$ (Osono et al. 2002). Based on these figures, the per capita deposition from nesting cormorants can be calculated as 4.5 to $11.5 \mathrm{~g} \mathrm{~d}^{-1} \mathrm{~N}$ and 2.1 to $3.2 \mathrm{~g} \mathrm{P} \mathrm{d}^{-1}$ (Hahn et al. 2007). Assuming a colony 


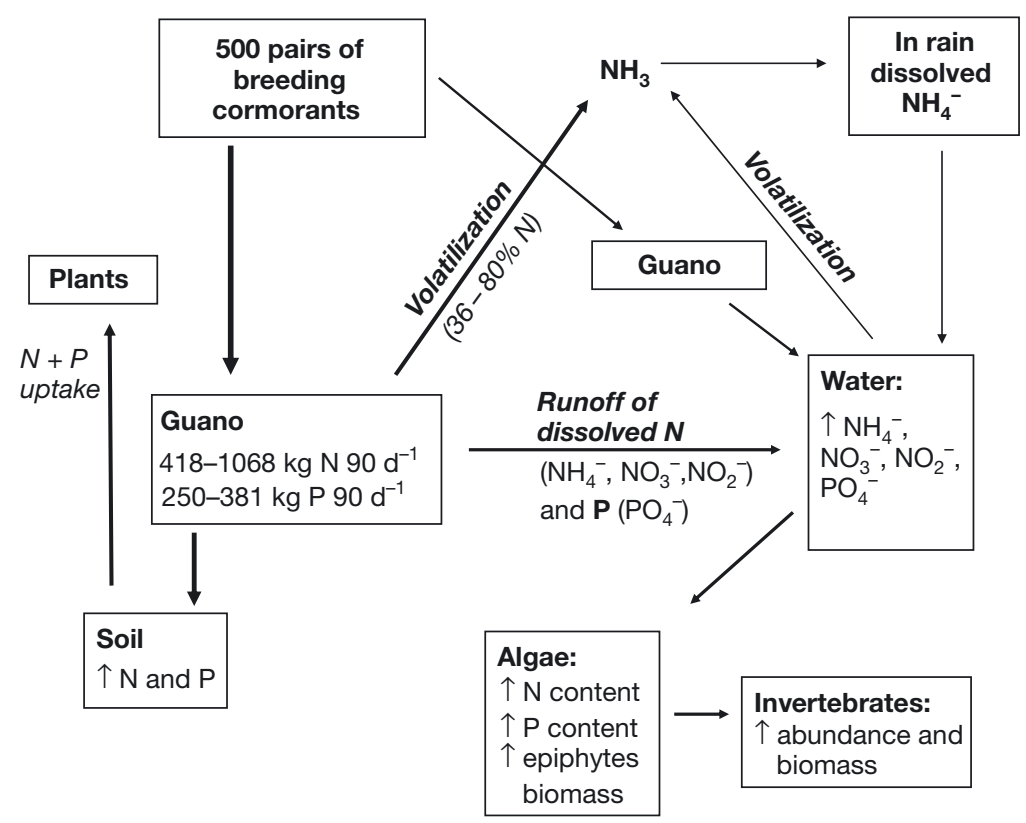

Fig. 1. Conceptual model illustrating the estimated nutrient flows on and around cormorant islands with high nest density (500 nests) and expected changes in nutrient content and biomass of algae and invertebrates in coastal waters. Vertical arrows in boxes denote an increase

with 500 nests and a breeding success of 1.3, this yields a nutrient load of 418 to $1068 \mathrm{~kg} \mathrm{~N}$ and 250 to $381 \mathrm{~kg} \mathrm{P}$ after 90 breeding days. The principal form of $\mathrm{P}$ in fresh guano is $\mathrm{PO}_{4}^{-}(54 \%$; Lindeboom 1884, Staunton Smith \& Johnson 1995) whereas guano-N is dominated by uric acid (50 to $80 \%$ ). The other major $\mathrm{N}$-containing compound in guano is $\mathrm{NH}_{4}{ }^{+}$, making up 8 to $40 \%$, while amino acids and proteins occur in smaller amounts (Lindeboom 1884, Schmidt et al. 2004). After guano deposition on the island, ammonia volatilizes rapidly from the uric acid and causes 25 to $80 \%$ losses of total guano-N (Lindeboom 1884, Staunton Smith \& Johnson 1995). In water, nutrients from the guano are rapidly dissolved, and most dissolved $\mathrm{N}$ occurs as $\mathrm{NH}_{4}{ }^{+}$(Loder et al. 1996).

In the present study, we utilized 18 islands: 7 active cormorant islands with various nest densities, 2 recently abandoned cormorant nesting islands, and 9 islands without nesting cormorants (Table 1). Among these islands, 12 were located in the northern part of the archipelago $\left(59^{\circ} 30^{\prime}\right.$ to $41^{\prime} \mathrm{N}, 18^{\circ} 32^{\prime}$ to $19^{\circ} 02^{\prime} \mathrm{E}$ ) and 6 in the southern part $\left(58^{\circ} 52^{\prime}\right.$ to $59^{\circ} 06^{\prime} \mathrm{N}, 17^{\circ} 54^{\prime}$ to $18^{\circ} 21^{\prime} \mathrm{E}$ ) (Fig. 2). Because our previous data indicated that ornithogenic nitrogen only enters surrounding waters in detectable amounts at high nest densities (Kolb et al. 2010), we grouped the active cormorant island into 2 categories according to their nest density: 3 islands with a low $\left(<0.03\right.$ nests $\left.\mathrm{m}^{-2}\right)$ and 4 islands with a high (>0.03 nests $\mathrm{m}^{-2}$ ) nest density. When selecting reference islands, we chose islands in the same range of size, distance to the mainland, wave exposure, and vegetation structure as the cormorant islands, to reduce the probability of confounding results (Table 1). Cormorants are sensitive to human disturbance, and colonies in the Stockholm archipelago are typically established on islands with limited activity (R. Staav pers. comm.). No other island characteristics predicted cormorant presence or nest density. Wave exposure was calculated as effective fetch (distance of free water) in 16 directions for each sample sides with the help of the program WaveImpact (Isæus 2004) (Table 1). We excluded one active cormorant island (Våmkubben) with a high nest density from the statistical analyses because its unusual topography made bottom-up effects from cormorants on the focal species extremely unlikely. Våmkubben is a very steep and exposed island, and the cormorant colony is concentrated on a side without a Fucus belt. Because of the steep slope, the runoff is concentrated on this side, and the side with the Fucus belt can be expected to receive only a small amount of the nutrient runoff that is rapidly dispersed due to the high wave exposure. Comparison of algal $\delta^{15} \mathrm{~N}$ ratios from Våmkubben with reference islands, having similar wave exposure, supported our assumption that only a very low concentration of ornithogenic $\mathrm{N}$ was dissolved in the water around the Fucus belts of Våmkubben. Fucus from Våmkubben were depleted in ${ }^{15} \mathrm{~N}\left(\Delta \delta^{15} \mathrm{~N}=-3.5\right)$, and epiphytic algae were only slightly enriched $\left(\Delta \delta^{15} \mathrm{~N}=\right.$ 3.0).

Fucus vesiculosus is the most common and widespread canopy-forming species in the Baltic Sea and is considered to have an important function as habitat for a number of invertebrate species. During the last decades, Fucus has declined strongly (Malm \& Isæus 2005). This decline has been explained among others by indirect effects of eutrophication (e.g. Worm et al. 2000, Berger et al. 2003). In the present study, the most common epiphytic algae associated with Fucus were the brown algae Ectocarpus siliculosus and Elachista fuciola, the red algae Ceramium spp., and the green algae Enteromorpha spp. and Cladophora spp. Generally, algae take up $\mathrm{N}$ mainly as ammonium and nitrate, but for many algae ammonium is the preferred inorganic N source (Takamura \& Iwakuma 1991, Lobban \& Harrison 1994).

The most abundant grazers associated with Fucus were the mollusc Theodoxus fluviatilis; the crustaceans Jaera albifrons, Gammarus spp. and Idotea spp.; 
Table 1. Characteristics of 18 islands studied (cormorant nesting islands and reference [i.e. non-cormorant] islands) in the Stockholm archipelago, Baltic Sea. Locations are shown in Fig. 2. Wave exposure was calculated as effective fetch (distance of free water) in 16 directions for both Fucus sample sides (A \& B) for each island with the help of the program WaveImpact (Isæus 2004)

\begin{tabular}{|llclc|}
\hline Location & $\begin{array}{l}\text { Island } \\
\left(\text { nest } \mathrm{m}^{-2}\right)\end{array}$ & $\begin{array}{c}\text { Active nest } \\
\text { density }\end{array}$ & Island category & Wave exposure \\
\hline 1 & Marskärskobben & 0.025 & Active with low nest density & A 19060; B 18821 \\
1 & Fårörarna & 0 & Reference & A 21710; B 21710 \\
2 & Stora Träskär & 0 & Abandoned & A 52051; B 51900 \\
2 & Stora Halmören & 0 & Abandoned & A 51374; B 50072 \\
2 & Västra Mellgrund & 0 & Reference & A 50567; B 50393 \\
2 & Ägglösen & 0 & Reference & A 71649; B 77045 \\
3 & Bergskärit & 0.029 & Active with low nest density & A 16834; B 19002 \\
3 & Mjölingsören & 0 & Reference & A 17361; B 17361 \\
4 & Nickösören & 0 & Reference & A 9793; B 9783 \\
4 & Hannaholmen & 0 & Reference & A 7616; B 8023 \\
4 & Norra Ryssmasterna & 0.039 & Active with high nest density & A 9524; B 9202 \\
4 & Norra Småholmen & 0.063 & Active with high nest density & A 6785; B 7738 \\
5 & Fredagen & 0 & Reference & A 11073; B 10883 \\
5 & Skraken & 0.024 & Active with low nest density & A 8846; B 8613 \\
6 & Våmkubben & 0.041 & Active with high nest density & A 340983; B340983 \\
6 & Rödkläppen & 0 & Reference & A 382085; B388320 \\
6 & Fälöv & 0.034 & Active with high nest density & A 181913; B 180627 \\
6 & Skorvan & 0 & Reference & A 297421; B 298047 \\
\hline
\end{tabular}

and Chironomidae (insect). Here we focused on these 5 taxa because they are all known to feed at least partly on Fucus or its epiphytic macro- and microalgae (Sjöberg 1967, Goecker \& Kall 2003, Korpinen et al. 2008). J. albifrons grazes on microalgae, bacteria, and macroalgae (Sjöberg 1967, Pavia et al. 1999). T. fluviatilis is a scraper feeding primarily on periphyton (Liess \& Haglund 2007), whereas Gammarus spp. and Idotea spp. are shredders (Schwoerbel 1993) feeding mostly on macroalgae in the Baltic Sea (Goecker \& Kall 2003). Chironomidae is a species-rich family that, in the Stockholm archipelago, is dominated by herbivores and detritivores (Y. Brodin pers. comm.).

Sampling. We located Fucus belts by snorkelling around the islands, within 1 to $4 \mathrm{~m}$ from the shoreline. We chose 2 representative sample sites per island, if possible on opposite island sides. We randomly collected 6 Fucus fronds per island, 3 fronds per sample site. On 4 islands, an extra Fucus frond was collected to ensure a sufficient number of invertebrate samples for stable isotope analysis. Samples were collected 0.5 to $5 \mathrm{~m}$ from the shoreline, and at 0.5 to $2 \mathrm{~m}$ depth. We used a $0.2 \mathrm{~m}^{2}$ frame with an attached net bag ( $1 \mathrm{~mm}$ mesh size) to collect samples from a standardized area (Råberg \& Kautsky 2007). Samples were immediately transferred into plastic bags and stored in the freezer until sorting. In the laboratory, samples were sorted; invertebrates ( $>1 \mathrm{~mm}$ ) were identified to family, genus, or species level and counted. Theodoxus fluviatilis, Gammarus spp. and Idotea spp. were divided into 3 size classes. For each island, subsamples of about 100 individuals of each taxon and size class were dried at $55^{\circ} \mathrm{C}$ to constant dry-weight and weighed. Based on the subsamples, mean island individual dry weights for each taxon and size class were used in combination with the abundance data to estimate the total biomass (measured as dry weight) for each taxon and Fucus sample. To calculate the ratio of epiphytic algae to Fucus in each sample, one branch of the Fucus frond was cleaned from all epiphytic algae by scraping. The uncleaned Fucus fronds, epiphytic-free Fucus, and the epiphytic algae were dried $\left(55^{\circ} \mathrm{C}\right)$ and weighed.

Stable isotope and nutrient content analysis. For stable isotope, N, and P content analysis, per Fucus frond, one sample from the young Fucus tips and from the major epiphytic algae of the Fucus frond were used. The Fucus samples were cleaned from epiphytes prior to analysis. For stable isotope and nitrogen analysis, 5 to 6 Fucus fronds were used per island, whereas for the phosphorus analysis only 2 fronds were used, one from each sampling side. The stable isotope signature and $\mathrm{N}$ content analyses were conducted for all 5 invertebrate groups. For each group up to 6 samples, if possible one sample per Fucus frond was analyzed per island. Individuals belonging to larger size classes were preferred in this analysis. If possible, animal specimens were analyzed individually, and only legs were used to avoid gut contents, but pooled samples of whole bodies were used for Chironomidae and Jaera albifrons because of their small individual weight $(<0.7 \mathrm{mg})$. Theodoxus fluviatilis was removed from its shell, and only the soft body was used for analysis. Animals were freeze-dried and algae oven-dried $\left(55^{\circ} \mathrm{C}\right)$ prior to analysis. 
Phosphorus content (\%P, dry mass basis) was assayed using persulphate digestion and ascorbatemolybdate colorimetry (Clesceri et al. 1998). The stable isotope ratios for $\mathrm{C}$ and $\mathrm{N}$ and nitrogen content were measured in an isotope ratio mass spectrometer (Europa Scientific Integra). Isotope ratios were calculated as deviations from the international limestone standard Vienna PeeDee Belemnite (VPDB) $\left(\delta^{13} \mathrm{C}\right)$ and from atmospheric $N\left(\delta^{15} \mathrm{~N}\right)$ in parts per thousand (\%o):

$$
\delta X=\left[\left(R_{\text {sample }} / R_{\text {standard }}\right)-1\right] \times 1000
$$

where $X$ is the heavier isotope of the element $\left({ }^{13} \mathrm{C}\right.$ or $\left.{ }^{15} \mathrm{~N}\right)$ and $R$ is the isotopic ratio $\left({ }^{13} \mathrm{C} /{ }^{12} \mathrm{C}\right.$ or $\left.{ }^{15} \mathrm{~N} /{ }^{14} \mathrm{~N}\right)$.

The stable isotope signature $\left(\delta^{13} \mathrm{C}\right.$ and $\left.\delta^{15} \mathrm{~N}\right)$ of primary producers is constrained by their habitat, their carbon and nitrogen source, their biochemical structure, and the photosynthetic mechanism (Fry 2006).

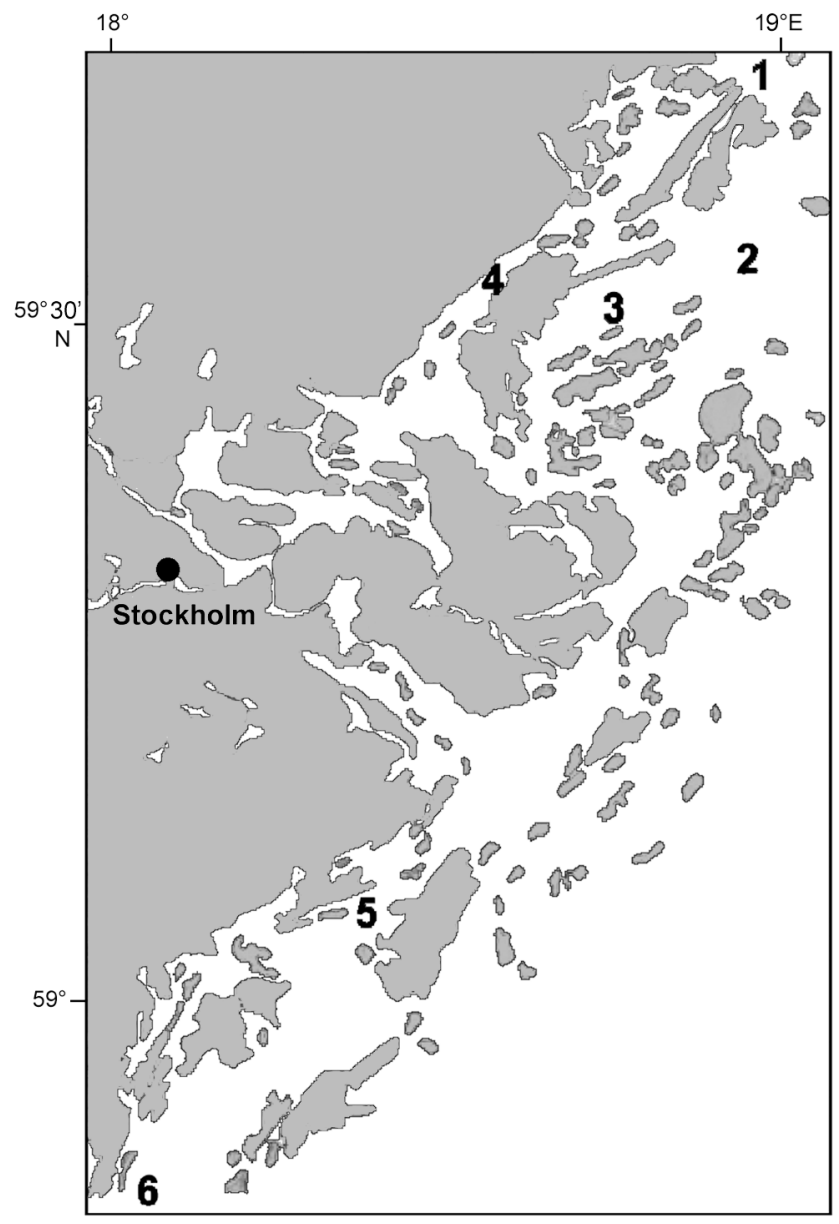

Fig. 2. Study areas in the Stockholm archipelago, Baltic Sea. (1) Marskärskobben and Fårörarna; (2) Stora Träskär, Stora Halmören, Västra Mellgrund, and Ägglösen; (3) Bergskärit and Mjölingsören; (4) Nickösören, Hannaholmen, Norra Ryssmasterna, and Norra Småholmen; (5) Fredagen and Skraken; and (6) Våmkubben, Rödkläppen, Fälöv, and Skorvan. Island characteristics are shown in Table 1
The $\delta^{13} \mathrm{C}$ and $\delta^{15} \mathrm{~N}$ signature of consumers is mainly constrained by their trophic level and diet; isotopic signatures typically reflect the isotope composition of food sources with some predictable changes (fractionation). While $\delta^{13} \mathrm{C}$ generally changes little between trophic levels, $\delta^{15} \mathrm{~N}$ shows a more distinct increase (McCutchan et al. 2003, Vanderklift \& Ponsard 2003). Fish-eating seabirds have enriched $\delta^{15} \mathrm{~N}$ signatures because of the marine diet and their high trophic position (Barrett et al. 2005), and seabird guano is often even more enriched in ${ }^{15} \mathrm{~N}$. This enrichment results from the rapid mineralization of uric acid, the main nitrogen content of guano, to ammonium $\left(\mathrm{NH}_{4}\right)$. The volatilization is accompanied by a large isotopic fractionation, leaving the remaining $\mathrm{NH}_{4}$ strongly enriched in the heavier ${ }^{15} \mathrm{~N}$ (Lindeboom 1984, Mizutani et al. 1986, Wainright et al. 1998). Primary producers taking up this enriched nitrogen from seabird guano therefore have enriched $\delta^{15} \mathrm{~N}$ ratios (Wainright et al. 1998). Consumers feeding on isotopically enriched primary producers also show distinguishably higher $\delta^{15} \mathrm{~N}$ signatures (Barrett et al. 2005). $\delta^{15} \mathrm{~N}$ can therefore be used to demonstrate the importance of avian nitrogen in food webs in and around seabird islands.

Statistical analyses. To investigate if algae and associated invertebrates near cormorant colonies incorporate ornithogenic $\mathrm{N}$ in their tissue, we compared stable isotope ratios $\left(\delta^{13} \mathrm{C}\right.$ and $\left.\delta^{15} \mathrm{~N}\right)$ among the 3 groups of cormorant islands and the reference islands using linear mixed effects models. Carbon and nitrogen isotope signatures were analyzed separately, with island category, adjusted wave exposure, and their interaction as fixed effects and islands as random effect. We excluded factors that did not contribute to the model ( $p>0.05)$. In order to meet the assumption of normality and homoscedasticity, we used adjusted wave exposure (i.e. the difference between wave exposure of the sample side and mean wave exposure [wave exposure log-transformed]) in all models. We included wave exposure as covariate because of its great variation between islands studied (Table 1), its effect on nutrient dispersal, and its likely effect on algae and invertebrate community structure (Bustamante \& Branch 1996, Eriksson et al. 2004).

Based on the $\delta^{13} \mathrm{C}$ and $\delta^{15} \mathrm{~N}$ ratios (island mean $\pm \mathrm{SD}$ ) of Fucus and epiphytic algae, we estimated the relative proportion of these food sources in the diet of 5 aquatic invertebrates with the software MixSIR (Moore \& Semmens 2008). MixSIR is a Bayesian mixing model that estimates probability distributions of source contributions to a mixture while explicitly accounting for uncertainty associated with multiple sources, fractionation, and isotope signatures (Moore \& Semmens 2008). MixSIR estimates not only the predicted proportion of food sources in the diet but also confidence 
intervals of these estimates. Means of different taxa were considered different when they were not included in the $95 \%$ confidence interval of the other group.

Before applying the diet mixing models, we standardized the lipid content of the samples (both sources and consumers) with a mathematical normalization technique (Post et al. 2007). This technique normalizes the $\delta^{13} \mathrm{C}$ ratio of a sample for its lipid content by using the $\mathrm{C}: \mathrm{N}$ ratios for animals and the $\% \mathrm{C}$ content for plants. The approach is based on the strong relationship between (1) C:N ratio of animals and their lipid content, (2) the $\mathrm{C}$ content of plants and their lipid content, and (3) the lipid content and the change in $\delta^{13} \mathrm{C}$ $\left(\Delta \delta^{13} C\right)$ (Post et al. 2007). The specific equations used were:

$$
\begin{aligned}
& \delta^{13} \mathrm{C}_{\text {normalized }}=\delta^{13} \mathrm{C}_{\text {untreated }}-3.32+0.99 \times \mathrm{C}: \mathrm{N} \\
& \text { for aquatic invertebrates } \\
& \delta^{13} \mathrm{C}_{\text {normalized }}=\delta^{13} \mathrm{C}_{\text {untreated }}-3.02+0.09 \times \% \mathrm{C} \\
& \text { for plants with } \mathrm{C}<40 \% \\
& \delta^{13} \mathrm{C}_{\text {normalized }}=\delta^{13} \mathrm{C}_{\text {untreated }}-5.83+0.14 \times \% \mathrm{C} \\
& \text { for plants with } \mathrm{C}>40 \%
\end{aligned}
$$

We calculated estimates of the carbon and nitrogen fractionation factors $\left(\delta^{13} \mathrm{C}\right.$ and $\left.\delta^{15} \mathrm{~N}\right)$ from the isotopic ratio of the 2 sources (Fucus and epiphytic algae) for each consumer by using the equations by Caut et al. (2009):

$$
\begin{aligned}
\delta^{13} \mathrm{C} & =-0.11 \delta^{13} \mathrm{C}-1.92 \\
\delta^{15} \mathrm{~N} & =-0.31 \delta^{15} \mathrm{~N}+4.06
\end{aligned}
$$

Diet mixing models were analysed with both untreated $\delta^{13} \mathrm{C}$ ratios and lipid-normalized $\delta^{13} \mathrm{C}$ ratios because it remains unclear if this normalization is necessary (Post et al. 2007), especially for aquatic invertebrates (Logan et al. 2008). While many studies using stable isotope analysis ignore lipid effects totally (Vander-Zanden \& Rasmussen 1999), other studies show strong effects of lipid-normalization on the results of diet mixing models (Kiljunen et al. 2006). By using a 2-source isotope mixing model including Fucus and epiphytic algae, we ignored other possible food sources like microalgae and bacteria. Theodoxus fluviatilis mainly feed on periphyton (Liess \& Haglund 2007), and our analysis might therefore be less useful for identifying diet changes for this species.

Linear mixed effects models were also used to test for differences in (1) the epiphytic algae to Fucus ratio, (2) nitrogen and phosphorus content of algae and invertebrate, (3) abundance, and (4) biomass of the 5 invertebrate groups between reference islands and the 3 cormorant island categories. Island category, adjusted wave exposure, and their interaction were used as fixed factors in this analysis, with island as random factor. In order to meet the assumption of normality and homoscedasticity, we transformed the response variables: epiphytic algae to Fucus ratio and invertebrate biomass (i.e. dry-weight invertebrates [mg] per dry-weight algae (Fucus and epiphytic algae) [g]) were square-root transformed, whereas invertebrate abundance (i.e. individuals per g dry-weight algae) was log transformed. All linear mixed effect models were performed using the nlme package in R.2.9.2 (R Development Core Team 2007).

\section{RESULTS}

\section{Stable isotope and nitrogen content analyses}

Stable isotope analyses showed that all algae and consumers collected nearby active cormorant islands with high nest densities were strongly enriched in $\delta^{15} \mathrm{~N}$ compared with reference islands (Fig. 3, Table 2). Fucus, epiphytic algae, and Chironomidae were more enriched in $\delta^{15} \mathrm{~N}\left(\Delta \delta^{15} \mathrm{~N}=11.3\right.$ to 11.7$)$ than Gammarus spp., Idotea spp. Jaera albifrons and Theodoxus fluviatilis $\left(\Delta \delta^{15} \mathrm{~N}=7.2\right.$ to 8.1$)$. Near islands with low nest densities, algae (Fucus: $\Delta \delta^{15} \mathrm{~N}=3.4$ and epiphytes:

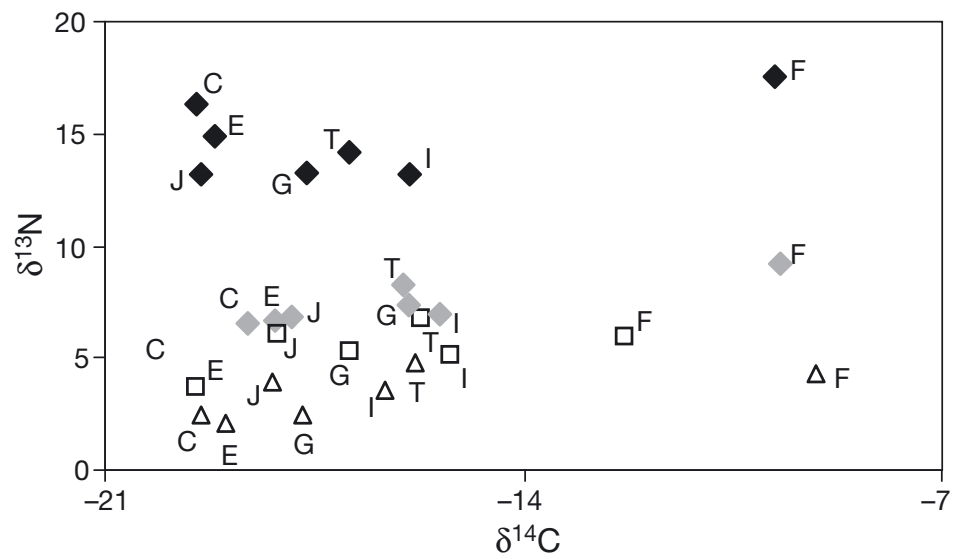

$\square$ Reference islands

Cormorant islands

$\triangle$ Abandoned

Active with low nest density

- Active with high nest density

F Fucus vesiculosus

E Epiphytic algae

C Chironomidae

T Theodoxus fluviatilis

G Gammarus spp.

I Idotea spp.

$\mathbf{J}$ Jaera albifrons
Fig. 3. $\delta^{13} \mathrm{C}$ and $\delta^{15} \mathrm{~N}$ signatures of algae and 5 aquatic invertebrate groups from different islands in the Stockholm archipelago, Baltic Sea 
Table 2. Results of linear mixed effect models (lme) testing for differences in the $\delta^{15} \mathrm{~N}$ signatures of algae and aquatic invertebrate groups between reference islands (i.e. noncormorant) and 3 categories of cormorant islands (abandoned, active with low and high nest densities). Samples were collected in the surrounding water bodies of 17 islands in the Stockholm archipelago, Baltic Sea. den df: denoted df. Note: Results from ANOVA table for lme are shown

\begin{tabular}{|lcccc|}
\hline Taxon & den df & $F$ & $\mathrm{p}$ & $\begin{array}{c}\text { Slope } \\
\text { (mean } \pm \text { SE) }\end{array}$ \\
\hline Fucus vesiculosus & 84 & & & \\
Island category & 13 & 28.1 & $<0.0001$ & \\
Wave exposure & 84 & 3.1 & 0.082 & $-0.7 \pm 0.4$ \\
Epiphytic algae & 136 & & & \\
Island category & 13 & 38.7 & $<0.0001$ & \\
Wave exposure & 136 & 8.9 & 0.004 & $-0.9 \pm 0.3$ \\
Chironomidae & 73 & & & \\
Island category & 13 & 28.6 & $<0.0001$ & \\
Wave exposure & 73 & 3.5 & 0.066 & $-1.0 \pm 0.4$ \\
Theodoxus fluviatilis & 60 & & & \\
Island category & 11 & 14.8 & $<0.001$ & \\
Wave exposure & 60 & 5.0 & 0.030 & $-1.0 \pm 0.5$ \\
Gammarus spp. & 103 & & & \\
Island category & 13 & 11.9 & $<0.001$ & \\
Wave exposure & 103 & 5.7 & 0.019 & $-1.0 \pm 0.5$ \\
Idotea spp. & 124 & & & \\
Island category & 13 & 11.1 & $<0.001$ & \\
Wave exposure & 124 & 10.4 & 0.002 & $-1.2 \pm 0.4$ \\
Jaera albifrons & 50 & & & \\
Island category & 11 & 17.9 & $<0.001$ & \\
Wave exposure & 50 & 4.8 & 0.033 & $-0.9 \pm 0.4$ \\
\hline
\end{tabular}

$\left.\Delta \delta^{15} \mathrm{~N}=2.8\right)$ but not consumers showed a tendency towards a slight $\delta^{15} \mathrm{~N}$ enrichment (Fig. 3, Table 2). All groups showed or tended to show decreasing $\delta^{15} \mathrm{~N}$ signatures with an increasing wave exposure (Table 2). T. fluviatilis was depleted in $\delta^{13} \mathrm{C}$ nearby cormorant islands with a high nest density $\left(\Delta \delta^{13} \mathrm{C}=-1.2\right.$, den df (denoted df $)=11$ and 60, $F=2.6, \mathrm{p}=0.10)$, and $J$. albifrons showed a similar tendency $\left(\Delta \delta^{13} \mathrm{C}=-1.3\right.$, den $\mathrm{df}=$ 11 and $51, F=1.8, \mathrm{p}=0.20)$. T. fluviatilis tended to have increasing $\Delta \delta^{13} \mathrm{C}$ signatures with an increasing wave exposure $(F=3.4, \mathrm{p}=0.07)$. The interaction island type $\times$ wave exposure did in no case contribute significantly to isotope variation.

Both diet mixing models, with untreated $\delta^{13} \mathrm{C}$ ratios (model I) or with lipid-normalized $\delta^{13} \mathrm{C}$ ratios (model II), indicated that all consumers except Chironomidae tended to higher relative consumption of epiphytic algae near active cormorant islands with high nest density compared to reference islands, but the tendency was more pronounced in model II (Fig. 4). Such an increased consumption of epiphytes was also found for Theodoxus fluviatilis, Idotea spp. (both models), and Gammarus spp. (only model I). Near cormorant islands with low nest densities and abandoned cor-

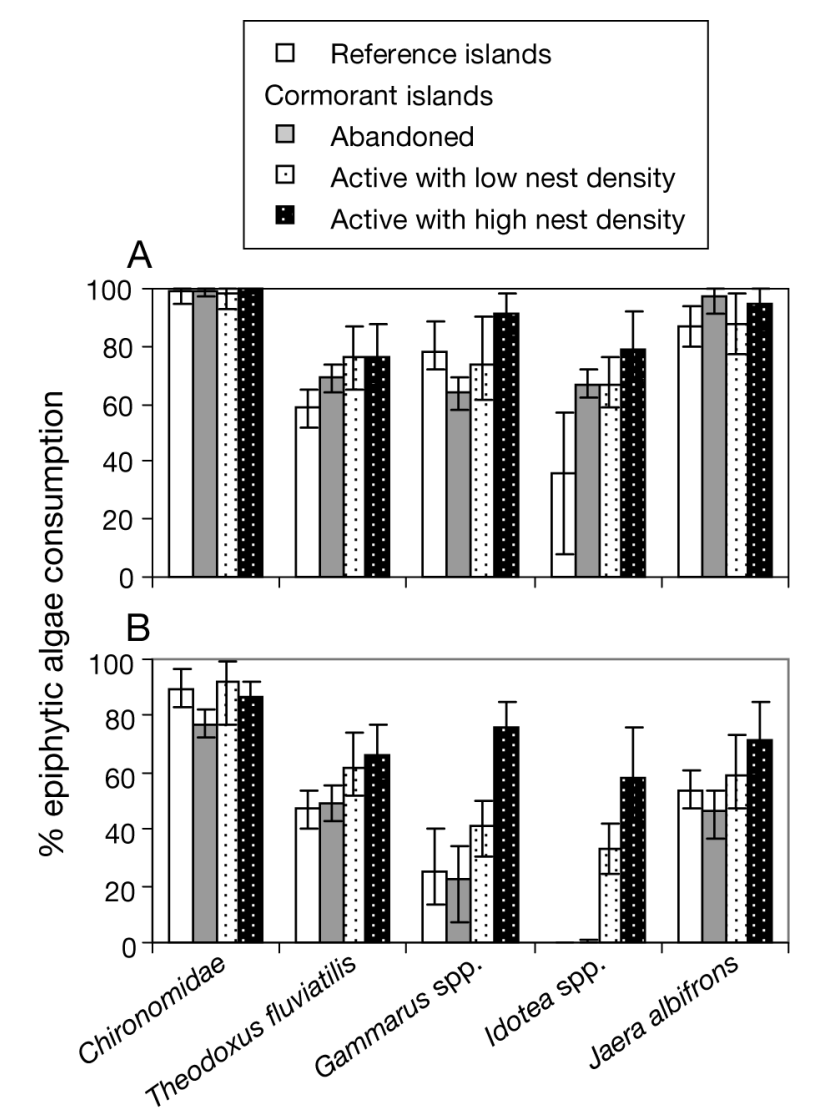

Fig. 4. Percent consumption of epiphytic algae (epiphyte) (median $\pm 95 \% \mathrm{CI}$ ) of aquatic invertebrate groups collected in coastal waters of reference islands $(\mathrm{n}=9)$, abandoned cormorant islands $(\mathrm{n}=2)$, and active cormorant islands with low $(\mathrm{n}=3)$ and high $(\mathrm{n}=3)$ nest density in the Stockholm archipelago, Sweden. Percent consumption was calculated with diet mixing models (MixSIR). (A) Untreated $\delta^{13} \mathrm{C}$ ratios were used for the models. (B) Lipid-normalized $\delta^{13} \mathrm{C}$ ratios were used for the models (Post et al. 2007)

morant islands, the pattern was less clear and differed between the models and among taxa (Fig. 4). Generally, model I predicted a higher percentage epiphyte consumption than model II. However, both models indicate that Idotea spp. was the group with the highest degree of Fucus feeding, whereas Chironomidae was the group with the lowest degree of Fucus feeding (Fig. 4).

Fucus and epiphytic algae around cormorant islands with a high nest density had $61 \%$ and $57 \%$, respectively, higher $\mathrm{N}$ content than algae around reference islands (Fig. 5, Table 3). Of the 5 invertebrate groups, only Idotea spp. had a higher $\mathrm{N}$ content (15\%) near islands with high nest densities than near reference islands (Fig. 5, Table 3). There were no differences in $\mathrm{N}$ content for any group between islands with a low nest density and reference islands. Gammarus spp. tended towards lower $\mathrm{N}$ content near abandoned cormorant islands compared to reference islands (Fig. 5, Table 3). The N con- 
A)
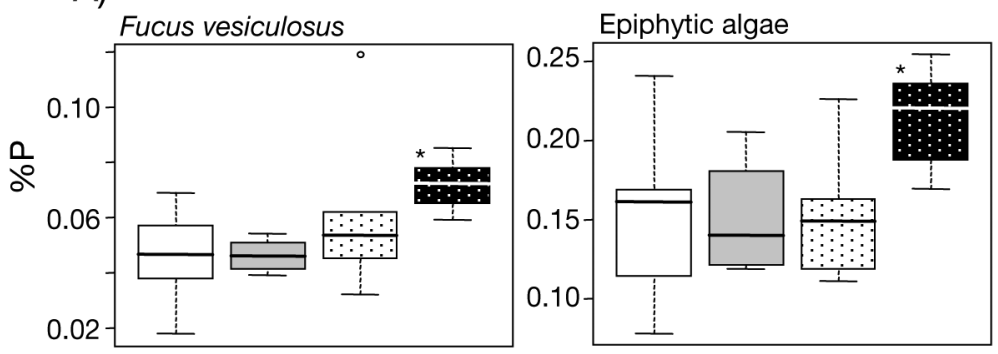

B)
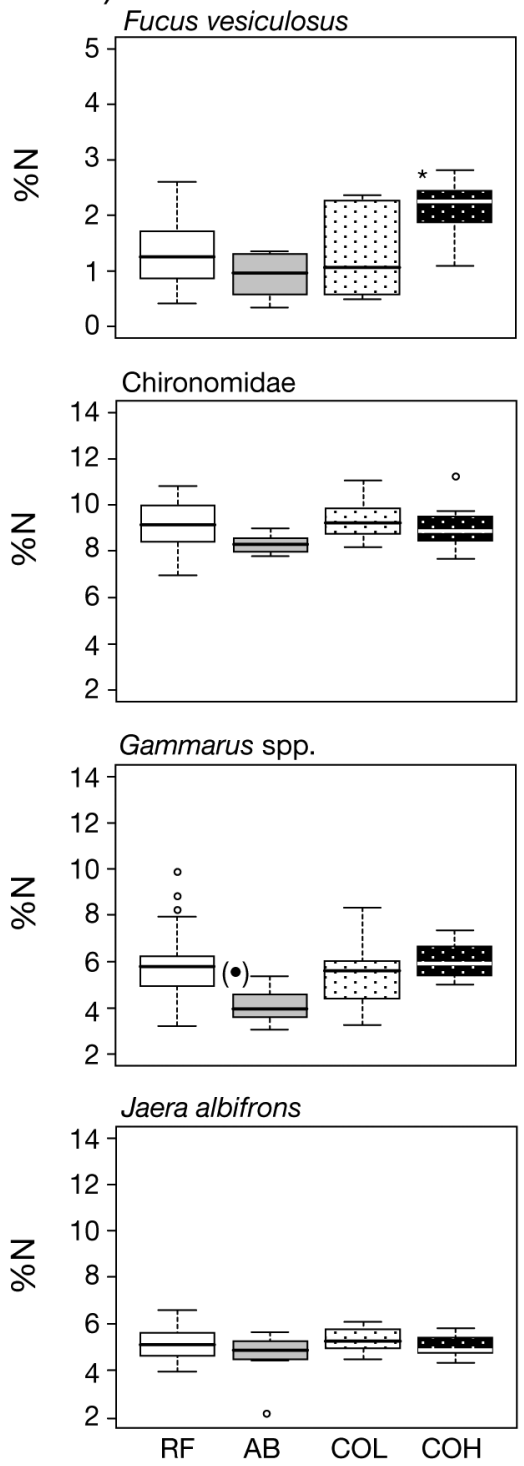

Fig. 5. (A) Phosphorus content of algae and (B) nitrogen content of algae and aquatic invertebrate groups collected in coastal waters of 4 island categories in the Stockholm archipelago, Baltic Sea. Shown are median values of the response variable with upper box showing 75 th percentile, lower box showing 25th percentile, and whiskers showing values within the range of 1.5 interquartile distances. $(\bullet) \mathrm{p}<0.1,{ }^{*} \mathrm{p}<0.05,{ }^{* *} \mathrm{p}<0.01$, ${ }^{* * *} \mathrm{p}<0.001$ refer to level of significance for difference in $\mathrm{N}$ and $\mathrm{P}$ content relative to reference islands tent of Chironomidae was negatively correlated to wave exposure, and epiphytic algae tended towards the same negative correlation (Table 3). There was a significant interaction between island category and wave exposure for the $\mathrm{N}$ content of Jaera albifrons, which was due to a negative correlation with wave exposure near reference islands but slightly positive correlation near active cormorant islands with high nest density. Also the P content of Fucus (54\% higher) and epiphytes (45\% higher) was higher nearby active cormorant islands than reference islands (Fig. 5, Table 3).

Fucus growing near cormorant islands with high nest density had $64 \%$ more epiphytic algae than Fucus nearby reference islands (den $\mathrm{df}=13$ and 85, $F=4.0, \mathrm{p}=0.033$ ) (Fig. 6). The epiphytic algae to Fucus ratio near active cormorant islands with a low nest density and near abandoned cormorant islands did not differ from the ratio near reference islands. Exposure did not affect the ratio.

\section{Invertebrate abundance and biomass}

Cormorant colonies with high nest densities affected the abundance of one and tended to do so of 2 out of 5 investigated aquatic invertebrate groups. Jaera albifrons was 2.6-fold more abundant around active islands with high cormorant nest densities than around reference islands. Chironomidae and Gammarus spp. tended to have a 3.2-fold and 3.4-fold higher abundance around high nest density islands than around reference islands (Fig. 7A, Table 4). The abundances of Theodoxus fluvi-

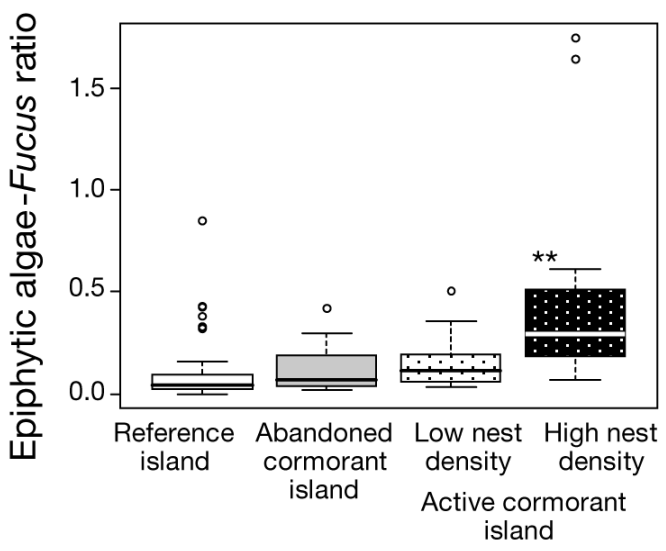

Fig. 6. Epiphytic algae:Fucus ratio of algae collected in coastal waters of 4 island categories in the Stockholm archipelago, Baltic Sea. See Fig. 5 for further explanations 
Table 3. Results of linear mixed effects model (lme) testing for differences in nitrogen $(\% \mathrm{~N})$ and phosphorus $(\% \mathrm{P})$ content of algae and aquatic invertebrate groups between reference (RF) (i.e. non-cormorant islands) and 3 categories of cormorant islands (abandoned [AB], active with low [COL] and with high $[\mathrm{COH}]$ nest densities). Samples were collected in water bodies surrounding 17 islands in the Stockholm archipelago, Baltic Sea. Note: ANOVA tables for lme are shown; when the interaction between island category and wave exposure was significant, wave exposure slopes are given for reference islands and island categories with a slope significant different to reference islands

\begin{tabular}{|c|c|c|c|c|}
\hline Taxon & den df & $F$ & $\mathrm{p}$ & $\begin{array}{c}\text { Slope } \\
(\text { mean } \pm \text { SE) }\end{array}$ \\
\hline \multicolumn{5}{|l|}{$\% \mathbf{N}$} \\
\hline Fucus vesiculosus & 85 & & & \\
\hline Island category & 13 & 4.1 & 0.030 & \\
\hline Epiphytic algae & 136 & & & \\
\hline Island category & 13 & 6.2 & 0.008 & \\
\hline Wave exposure & 136 & 3.1 & 0.083 & $-0.1 \pm 0.1$ \\
\hline Chironomidae & 73 & & & \\
\hline Island category & 13 & 0.3 & 0.811 & \\
\hline Wave exposure & 73 & 12.4 & 0.001 & $-0.4 \pm 0.1$ \\
\hline Theodoxus fluviatilis & 61 & & & \\
\hline Island category & 11 & 0.8 & 0.538 & \\
\hline Gammarus spp. & 47 & & & \\
\hline Island category & 13 & 1.7 & 0.224 & \\
\hline Idotea spp. & 125 & & & \\
\hline Island category & 13 & 3.9 & 0.033 & \\
\hline Jaera albifrons & 47 & & & \\
\hline Island category & 11 & 0.6 & 0.641 & \\
\hline Wave exposure & 47 & 37.8 & $<0.0001$ & $\begin{array}{c}\text { RF: }-0.8 \pm 0.1 \\
\text { AB: } 1.0 \pm 0.2\end{array}$ \\
\hline Island $\times$ Wave & 47 & 9.0 & $<0.0001$ & $\mathrm{COH}: 1.0 \pm 0.3$ \\
\hline \multicolumn{5}{|l|}{$\% \mathbf{P}$} \\
\hline Fucus vesiculosus & 17 & & & \\
\hline Island category & 13 & 3.0 & 0.070 & \\
\hline Epiphytic algae & 18 & & & \\
\hline Island category & 12 & 3.1 & 0.068 & \\
\hline
\end{tabular}

atilis and $J$. albifrons around reference islands and active cormorant islands with high nest density were negatively correlated with wave exposure (Table 4). The biomasses of J. albifrons, Gammarus spp., and Chironomidae were greater near islands with high nest densities than near reference islands. Near high nest density islands, Chironomidae had 5.6-fold, Gammarus spp. 1.8-fold, and J. albifrons 1.4-fold higher mean dry-weight per dry-weight algae than near reference islands (Fig. 7B, Table 4). There was a significantly interactive effect between island type and wave exposure for $J$. albifrons abundance and biomass and the biomass of T. fluviatilis and Gammarus spp., and this interaction was due to a more negative correlation with wave exposure around high nest density islands than around reference islands (Table 4).
Table 4. Results of linear mixed effect models testing for differences in abundance (individuals per $\mathrm{g}$ dry-weight algae) $(\log [\mathrm{x}+0.5]$ transformed) and biomass (mg dry-weight invertebrates per g dryweight algae) (square root transformed) of algae and aquatic invertebrate groups between reference (RF) (i.e. non-cormorant) islands and 3 categories of cormorant islands (abandoned $[\mathrm{AB}]$, active with low [COL] and high [COH] nest densities). Samples were collected in the surrounding water bodies of 17 islands in the Stockholm archipelago, Baltic Sea. See Table 3 for further explanations

\begin{tabular}{|lcccc|}
\hline Taxon & den df & $F$ & $p$ & $\begin{array}{c}\text { Slope } \\
\text { (mean } \pm \text { SE) }\end{array}$ \\
\hline Abundance & & & & \\
Chironomidae & 85 & & & \\
Island category & 13 & 1.3 & 0.331 & \\
Theodoxus fluviatilis & 84 & & & \\
Island category & 13 & 1.9 & 0.176 & \\
Wave exposure & 84 & 20.6 & $<0.0001$ & $-0.33 \pm 0.07$ \\
Gammarus spp. & 85 & & & \\
Island category & 13 & 1.4 & 0.295 & \\
Idotea spp. & 85 & & & \\
Island category & 13 & 2.5 & 0.109 & \\
Jaera albifrons & 81 & & & \\
Island category & 13 & 2.8 & 0.082 & \\
Wave exposure & 81 & 6.7 & 0.012 & RF: $-0.3 \pm 0.1$ \\
& & & & COH: $-0.6 \pm 0.2$ \\
Island $\times$ Wave & 81 & 3.1 & 0.033 & \\
Biomass & & & & \\
Chironomidae & 81 & & & \\
Island category & 13 & 2.5 & 0.057 & \\
Theodoxus fluviatilis & 84 & & & \\
Island category & 13 & 2.7 & 0.089 & \\
Wave exposure & 84 & 21.9 & $<0.0001$ & $-1.2 \pm 0.3$ \\
Gammarus spp. & 81 & & & \\
Island category & 13 & 7.6 & 0.004 & \\
Wave exposure & 81 & 0.6 & 0.458 & RF: $-0.2 \pm 0.2$ \\
Island $\times$ Wave & 81 & 6.4 & 0.001 & \\
Idotea spp. & 85 & & & \\
Island category & 13 & 0.6 & 0.602 & \\
Jaera albifrons & 81 & & & \\
Island category & 13 & 5.6 & 0.011 & \\
Wave exposure & 81 & 13.2 & 0.001 & RF: $-0.1 \pm 0.0$ \\
Island $\times$ Wave & 81 & 5.2 & 0.002 & \\
\hline
\end{tabular}

\section{DISCUSSION}

Seabirds can strongly affect the island ecosystem by fertilizing soils and subsidizing several trophic levels (Polis \& Hurd 1995, Ellis 2005, Towns et al. 2009). Our results showed, similar to earlier studies (Golovkin 1967, Bosman \& Hockey 1988, Wootton 1991, Lapointe et al. 1992), that seabirds affect not only the terrestrial ecosystem but also aquatic primary producers and their consumers near nesting islands. However, strong effects on algae and invertebrates were only observed near islands with a high nest density. In our system, 

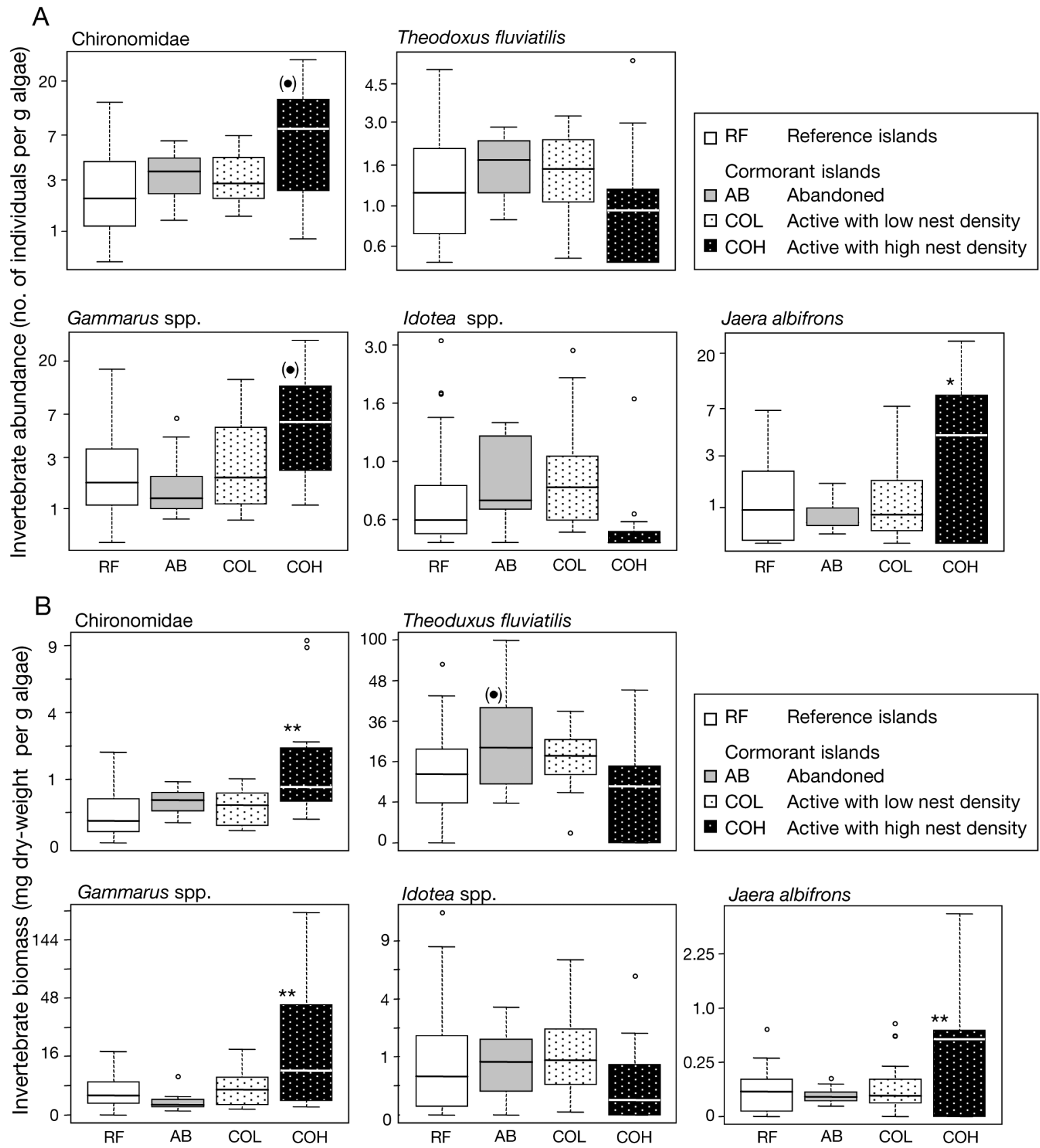

Fig. 7. (A) Abundance and (B) biomass of marine invertebrates (number of individuals per g dry-weight algae) collected in water bodies surrounding 4 island categories (reference islands [RF], abandoned cormorant islands [AB], active cormorant islands with low $[\mathrm{COL}]$ and high [COH] nest density) in the Stockholm archipelago, Baltic Sea. (A) Scale is log-transformed; (B) scale is squareroot transformed. See Fig. 5 for further explanations

ornithogenic $\mathrm{N}$ and P probably enter the surrounding water mainly via runoff and, in smaller amounts, via direct guano excretion into the water and in raindissolved ammonia, and significant runoff will likely only occur from islands with high nest density. The vegetation on islands with low nest density is probably able to take up most of the non-volatilized guano-N (Kolb et al. 2010), and most P will be taken up or bound in the soils on these islands. Increased nutrient con- centrations $\left(\mathrm{NH}_{4}{ }^{+}, \mathrm{NO}_{3}{ }^{-}, \mathrm{NO}_{2}{ }^{-}\right.$and $\left.\mathrm{PO}_{4}{ }^{-}\right)$in adjacent waters have been reported from other high nest density seabird islands (Bosman et al. 1986, Lapointe et al. 1992). However, nutrient concentration in waters surrounding seabird islands might not only depend on nest density but also on island structure and vegetation, wave exposure, and weather conditions (Loder et al. 1996, Young et al. 2011). Strong rains will flush much dry guano from the islands into the water and 
thus increase water nutrient concentration, whereas high temperatures and sunshine will increase volatilization of $\mathrm{NH}_{3}$ from the water and thus decrease $\mathrm{N}$ concentrations (Loder et al. 1996).

Seabird islands with a high nest density and a low wave exposure may be seen as a natural experiment for studying the effects of eutrophication on marine communities. We found, consistent with former fertilisation experiments, increased algal nitrogen and phosphorus content and a higher epiphytic algae to Fucus ratio on cormorant islands with an increased nutrient availability (Pedersen \& Borum 1996, Worm et al. 2000, Kraufvelin et al. 2006, Kraufvelin 2007, Råberg \& Kautsky 2008). Contrary to previous studies investigating the effect of nutrient enrichment, on grazers in the Baltic Sea (Kotta et al. 2000, Worm \& Sommer 2000, Kraufvelin et al. 2006, Kraufvelin 2007, Korpinen et al. 2010) and chironomids in Lake Michigan, USA (Blumenshine et al. 1997), not all invertebrates responded with increased abundance. Among the 5 invertebrate groups, only Jaera albifrons showed significantly higher density and biomass near cormorant islands with high nest densities. Gammarus spp. and Chironomidae similarly showed increased biomass, but the effect on density was non-significant. The different responses in biomass and abundance can be explained by a changed species composition towards larger species or larger-bodied individuals of the same species. A shift towards larger species in response to water nutrient enrichment has been reported for Chironomidae but not for Gammaridae (Blumenshine et al. 1997). Furthermore, all identified Gammarus species (G. oceanicus, G. zaddachi, G. salinus, and G. locusta) in our samples have about the same size (Barnes 1994). This indicates that the biomass increase of Gammarus spp. near cormorant islands with a high nest density was caused by increased individual body sizes.

Surprisingly, neither Idotea spp. nor Theodoxus fluviatilis showed increased abundances or biomasses near cormorant colonies. This pattern was unexpected considering (1) that Idotea have been shown to prefer filamentous algae over Fucus as food source (Karez et al. 2000, Goecker \& Kåll 2003, Orav-Kotta \& Kotta 2004 , but see also Jormalainen et al. 2001); (2) the positive relationships between epiphyte loads and grazer densities (Kotta et al. 2000, Worm \& Sommer 2000); (3) that Idotea baltica exhibited increased growth rate, egg size, and number when feeding on nitrate, ammonia, and phosphate-fertilized Fucus (Hemmi \& Jormalainen 2002); and (4) the general importance of nitrogen as a limiting factor for invertebrates (Mattson 1980, Elser et al. 2000). An explanation for the lack of response of Idotea spp. might be the role that Fucus plays as a habitat, providing not only food but also shelter against disturbance or predation (Orav-Korra
\& Kotta 2004, Wikström \& Kautsky 2007, Råberg \& Kautsky 2007). Idotea spp. is the largest-bodied genus among the investigated invertebrates. They are, with a dorsiventrally flattened body, well adapted to the large, tough branched Fucus. Therefore, they might be more dependent on Fucus as a shelter than the smaller Jaera albifrons, Gammarus spp. and Chironomidae. Furthermore, the isotopic diet mixing model indicated that Idotea spp. did not prefer epiphytic algae as a food source as strongly as the other invertebrates and had a relatively higher Fucus consumption. Our results from the diet mixing model are of particular interest considering that previous studies on the diet preference of invertebrates of the Baltic Sea rarely utilized stable isotope analysis and furthermore disagree in the preferred diet source of Idotea (Karez et al. 2000, Jormalainen et al. 2001, Goecker \& Kåll 2003). T. fluviatilis might, similarly to Idotea spp., suffer from decreased shelter but also from the increased filamentous algae load that competes with microalgae, an important food source for the scraping snails (Råberg \& Kautsky 2008).

The present study focused on the possible bottom-up effect of cormorants on producers and consumers in coastal waters surrounding their nesting islands and disregarded possible top-down effects of cormorants through fish consumption. Top-down effects from seabirds on several trophic levels have been observed in intertidal zones, in which seabirds prey on limpets, snails, and crabs (Ellis et al. 2007, Wooten 1992, Kurle et al. 2008), but it is debatable to what extent fisheating seabirds affect their prey populations (Draulans 1988). Most seabirds forage in large marine areas and share their prey with other predators (e.g. fishery, mammals, and predatory fishes), which makes it difficult to study their effect on the abundance of their prey and lower trophic levels. However, several studies have investigated the effect of cormorants, with differing results; but all studies are from rather closed aquatic systems with a clear separation between within an outside cormorant foraging range (Birt et al. 1987, Engström 2001, Lehikoinen 2005, Dalton et al. 2009). Similar studies are difficult in our more open study system since reference islands lay within the feeding range of cormorants. Furthermore, we only studied the effect of cormorants in coastal waters (>5 m distance from the shore line) and thus were not able to make any prediction about the size of the area affected by ornithogenic nutrients. However, we found in an unpublished study that aquatic vascular plants and algae showed enriched $\delta^{15} \mathrm{~N}$ ratios within $30 \mathrm{~m}$ of an active cormorant island with high nest density. Certainly wave exposure and water depth might also play important roles in determining the size of the impact zone, but our results nevertheless show that nesting cor- 
morants can affect algae and some invertebrates in coastal waters; however, additional studies are needed to understand if invertebrates mainly responded to the increased epiphytic algae load, the increased algal nitrogen content, or the increased algal phosphorus content.

Acknowledgements. We gratefully acknowledge S. Wikström and L. Jerling for advice, and A. Lindström, S. Jerling, and M. Jorborg for assistance in the field and in the lab. S. Wikström and anonymous reviewers provided helpful comments on the manuscript. Funding was provided by the Swedish Research Council Formas (to P.A.H.).

\section{LITERATURE CITED}

Barnes RSK (1994) The brackish-water fauna of northwestern Europe. Cambridge University Press, New York

Barrett K, Anderson WB, Wait DA, Grismer LL, Polis GA, Rose MD (2005) Marine subsidies alter the diet and abundance of insular and coastal lizard populations. Oikos 109: 145-153

Berger R, Henriksson H, Kautsky L, Malm T (2003) Effects of filamentous algae and deposited matter on the survival of Fucus vesiculosus L. Germlings in the Baltic Sea. Aquat Ecol 37:1-11

Birt VL, Birt TP, Goulet D, Cairnse DK, Montevecchi WA (1987) Ashmole's halo: direct evidence for prey depletion by a seabird. Mar Ecol Prog Ser 40:205-208

Blumenshine SC, Vadeboncoeur Y, Lodge DM, Cottingham KL, Knight SE (1997) Benthic-pelagic links: responses of benthos to water-column nutrient enrichment. J N Am Benthol Soc 16:466-479

Bosman AL, Hockey PAR (1986) Seabird guano as a determinant of rocky intertidal community structure. Mar Ecol Prog Ser 32:247-257

Bosman AL, Hockey PAR (1988) The influence of seabird guano on the biological structure of rocky intertidal communities on islands off the west coast of southern Africa. S Afr J Mar Sci 7:61-68

Bosman AL, Dutoit JT, Hockey PAR, Branch GM (1986) A field experiment demonstrating the influence of seabird guano on intertidal primary production. Estuar Coast Shelf Sci 23:283-294

Bustamante RH, Branch GM (1996) Large scale patterns and trophic structure of southern African rocky shore: the role of geographic variation and wave exposure. J Biogeogr 23:339-351

- Caut S, Angulo E, Courchamp F (2009) Variation in discrimination factors $\left(\delta^{15} \mathrm{~N}\right.$ and $\left.\delta^{13} \mathrm{C}\right)$ : the effect of diet isotopic values and applications for diet reconstruction. J Appl Ecol 46:443-453

Clesceri LS, Greenberg AE, Eaton AD (1998). Standard methods for the examination of water and wastewater. American Public Health Association, New York

> Dalton CM, Ellis D, Post DM (2009) The impact of doublecrested cormorant (Phalacrocorax auritus) predation on anadromous alewife (Alosa pseudoharengus) in southcentral Connecticut, USA. Can J Fish 66:177-180

> De Jonge VM, Elliott M, Orive E (2002) Causes, historical development, effects and future challenges of a common environmental problem: eutrophication. Hydrobiologia 475(1):1-19
Draulans D (1988) Effects of fish-eating birds on fresh-water fish stocks - an evaluation. Biol Cons 44:251-263

Ellis JC (2005) Marine birds on land: a review of plant biomass, species richness, and community composition in seabird colonies. Plant Ecol 181:227-241

Ellis JC, Shulman MJ, Wood M, Witman JD, Lozyniak C (2007) Regulation of intertidal food webs by avian predators on New England rocky shores. Ecology 88:853-863

> Elmgren R (2001) Understanding human impact on the Baltic ecosystem: changing views in recent decades. Ambio 30: $222-231$

Elser JJ, Fagan WF, Denno RF, Dobberfuhl DR and others (2000) Nutritional constraints in terrestrial and freshwater food webs. Nature 408:578-580

Elser JJ, Matthew MES, Cleland EE, Gruner DS and others (2007) Global analysis of nitrogen and phosphorus limitation of primary producers in freshwater, marine and terrestrial ecosystems. Ecol Lett 10:1135-1142

Engström H (2001) Long term effects of cormorant predation on fish communities and fishery in a freshwater lake. Ecography 24:127-138

> Eriksson BK, Sandström A, Isæus M, Schreiber H, Karås P (2004) Effects of boating activities on aquatic vegetation in the Stockholm archipelago, Baltic Sea. Estuar Coast Shelf Sci 61:339-349

Fry B (2006) Stable isotope ecology. Springer, New York

> Goecker ME, Kåll SE (2003) Grazing preferences of marine isopods and amphipods on three prominent algal species of the Baltic Sea. J Sea Res 50:309-314

Golovkin AN (1967) The effect of colonial sea birds on development of the phytoplankton. Oceanology (Mosc) 7 : 521-529

Golovkin AN, Garkavaya GP (1975) Fertilization of waters off the Murmansk coast by bird excreta near various types of colonies. Sov J Mar Biol 1:345-351

Grover JP (1997) Resource competition. Chapman and Hall, London

Hahn S, Bauer S, Klaassen M (2007) Estimating the contribution of carnivorous waterbirds to nutrient loading in freshwater habitats. Freshw Biol 52:2421-2433

> Hemmi A, Jormalainen V (2002) Nutrient enhancement increases performance of a marine herbivore via quality of its food algae. Ecology 83:1052-1064

Hutchinson GE (1950) Survey of existing knowledge of biogeochemistry. 3. The biogeochemistry of vertebrate excretion. Bull Am Mus Nat Hist 96:1-554

Jormalainen V, Honkanen T, Heikkilä N (2001) Feeding preferences and performance of a marine isopod on seaweed hosts: cost of habitat specialization. Mar Ecol Prog Ser 220: 219-230

Karez R, Engelbert S, Sommer U (2000) 'Co-consumption' and 'protective coating': two new proposed effects of epiphytes on their macroalgal hosts in mesograzer-epiphytehost interactions. Mar Ecol Prog Ser 205:85-93

Keatley BE, Douglas MSV, Blais JM, Mallory ML, Smol JP (2009) Impacts of seabird-derived nutrients on water quality and diatom assemblages from Cape Vera, Devon Island, Canadian High Artic. Hydrobiol 621:191-205

Kiljunen M, Grey J, Sinisalo T, Harrod C, Immonen H, Jones RI (2006) A revised model for lipid-normalizing delta C-13 values from aquatic organisms, with implications for isotope mixing models. J Appl Ecol 43:1213-1222

Kolb GS, Jerling L, Hambäck PA (2010) The impact of cormorants on plant-arthropod food webs on their nesting islands. Ecosystems 13:353-366

Korpinen S, Jormalainen V, Honkanen T (2007) Effects of nutrients, herbivory, and depth on the marcoalgae community in the rocky sublittoral. Ecology 88:839-852 
Korpinen S, Jormalainen V, Ikonen J (2008) Selective consumption and facilitation by mesograzers in adult and colonizing macroalgal assemblages. Mar Biol 154:787-794

Korpinen S, Jormalainen V, Pettay E (2010) Nutrient availability modifies abundance and community structure of Fucus-associated littoral benthic fauna. Mar Environ Res 70:283-292

Kotta J, Paalme T, Martin G, Makinen A (2000) Major changes in macroalgae community composition affect the food and habitat preference of Idotea baltica. Int Rev Hydrobiol 85:697-705

Kraufvelin P (2007) Responses to nutrient enrichment, wave action and disturbance in rocky shore communities. Aquat Bot 87:262-274

Kraufvelin P, Salovius S, Christie H, Moy FE, Karez R, Pedersen MF (2006) Eutrophication-induced changes in benthic algae affect the behaviour and fitness of the marine amphipod Gammarus locusta. Aquat Bot 84:199-209

Kurle CM, Croll DA, Tershy BR (2008) Introduced rats indirectly change marine rocky intertidal communities from algae- to invertebrate-dominated. Proc Natl Acad Sci 105: 3800-3804

> Lapointe BE, Littler MM, Littler DS (1992) Nutrient availability to marine macroalgae in siliciclastic versus carbonaterich coastal waters. Estuaries 15:75-82

Lehikoinen A (2005) Prey-switching and diet of the great cormorant during the breeding season in the Gulf of Finland. Waterbirds 28:511-515

Liess A, Haglund AL (2007) Periphyton responds differentially to nutrients recycled in dissolved or faecal pellet form by the snail grazer Theodoxus fluviatilis. Freshw Biol 52:1997-2008

Lindeboom HJ (1984) The nitrogen pathway in a penguin rookery. Ecology 65:269-277

Lobban CS, Harrison PJ (1994) Seaweed ecology and physiology. Cambridge University Press, New York

> Loder TC III, Ganning B, Love JA (1996) Ammonia nitrogen dynamics in costal rockpools affected by gull guano. J Exp Mar Biol Ecol 196:113-129

Logan JM, Jardine TD, Miller TJ, Bunn SE, Cunjak RA, Lutcavage ME (2008) Lipid corrections in carbon and nitrogen stable isotope analyses: comparison of chemical extraction and modelling methods. J Anim Ecol 77: 838-846

Malm T, Isæus M (2005) Distribution of marcoalgal communities in the central Baltic Sea. Ann Bot Fenn 42:257-266

> Marion L, Clergeau, Brient L, Bertru G (1994) The importance of avian-contributed nitrogen $(\mathrm{N})$ and phosphorus $(\mathrm{P})$ to Lake Grand Lieu, France. Hydrobiologia 279-280: 133-147

Mattson WJ (1980) Herbivory in relation to plant nitrogencontent. Annu Rev Ecol Syst 11:119-161

McCutchan JH, Lewis WM, Kendall C, McGrath CC (2003) Variation in trophic shift for stable isotope ratios of carbon, nitrogen, and sulfur. Oikos 102:378-390

Michelutti N, Keatley BE, Brimble S, Blais JM and others (2009) Seabird-driven shifts in Arctic pond ecosystems. Proc Biol Sci 276:591-596

Mizutani H, Hasegawa H, Wada E (1986) High nitrogen isotope ratio for soils of seabird rookeries. Biochem 2: 221-247

Moore JW, Semmens BX (2008) Incorporating uncertainty and prior information into stable isotope mixing models. Ecol Lett 11:470-480

> Onuf CP, Teal JM, Valiela I (1977) Interactions of nutrients, plants growth and herbivory in a mangrove ecosystem. Ecology 58:514-526

> Orav-Kotta H, Kotta J (2004) Food and habitat choice of the isopod Idotea baltica in the northeastern Baltic Sea. Hydrobiol 514:79-85
Osono T, Hobara S, Fujiwara, Koba K, Kameda K (2002) Abundance, diversity, and species composition of fungal communities in a temperate forest affected by excreta of the Great Cormorant Phalacrocorax carbo. Soil Biol Biochem 34:1537-1547

Paillisson JM, Carpentier A, Le Gentil J, Marion L (2004) Space utilization by a cormorant (Phalacrocorax carbo L.) colony in a multi-wetland complex in relation to feeding strategies. C R Biol 327:493-500

Palomo G, Iribarne O, Martinez MM (1999) The effect of migratory seabirds guano on the soft bottom community of a SW Atlantic coastal lagoon. Bull Mar Sci 65:119-128

Pavia H, Carr H, Åberg P (1999) Habitat and feeding preferences of crustacean mesoherbivores inhabiting the brown seaweed Asophyllum nodosum (L.) Le Jol. and its epiphytic marcoalgae. J Exp Mar Biol Ecol 236:15-32

Pedersen MF, Borum J (1996) Nutrient reference of algal growth in estuarine waters. Nutrient limitation and the importance of nitrogen requirements and nitrogen storage among phytoplankton and species of macroalgae. Mar Ecol Prog Ser 142:261-272

> Polis GA, Hurd SD (1995) Extraordinarily high spider densities on islands - flow of energy from the marine to terrestrial food webs and the absence of predation. Proc Natl Acad Sci USA 92:4382-4386

Post DM, Layman CA, Arrington DA, Takimoto G, Quattrochi J, Montana CG (2007) Getting to the fat of the matter: models, methods and assumptions for dealing with lipids in stable isotope analyses. Oecologia 152:179-189

Postel SL, Carpenter SR (1997) Freshwater ecosystem services. In: Daily G (ed) Nature's services. Island Press, Washington, DC, p 195-214

Råberg S, Kautsky L (2007) A comparative biodiversity study of the associated fauna of perennial fucoids and filamentous algae. Estuar Coast Shelf Sci 73:249-258

> Råberg S, Kautsky L (2008) Grazer identity is crucial for facilitating growth of the perennial brown alga Fucus. Mar Ecol Prog Ser 361:111-118

> Rolff C, Elmgren R, Voss M (2008) Deposition of nitrogen and phosphorus on the Baltic Sea: seasonal patterns and nitrogen isotope composition. Biogeosciences 5:1657-1667

Rönnberg C, Bonsdorff E (2004) Baltic Sea eutrophication: area-specific ecological consequences. Hydrobiologia 514: $227-241$

- Schmidt S, Dennison WC, Moss GJ, Stewart GR (2004) Nitrogen ecophysiology of Heron Islands, a subtropical coral cay of the Great Barrier Reef, Australia. Funct Plant Biol 31:517-528

Schwoerbel J (ed) (1993) Einführung in die Limnologie, 7. Aufl. Gustav Fischer Verlag, Stuttgart/Jena/New York

Sjöberg B (1967) On the ecology of the Jaera albifrons group (Isopoda). Sarsia 29:321-348

Smith VH (2003) Eutrophication of freshwater and coastal marine ecosystems - a global problem. Environ Sci Poll Res 10:126-139

Staav R (2008) Skarv. In: Standfager K, Palmblad U (eds) Levande skärgårdsnatur 2008 - med rapporter från 2007. Skärgårdsstiftelsen, Stockholm

Staav R (2009) Ringmärkning av kustfåglar. In: Wibjörn C, Palmblad U (eds) Levande skärgårdsnatur 2009-med rapporter från 2007. Skärgårdsstiftelsen, Stockholm

Staav R (2010) Ringmärkning av kustfåglar. In: Standfager K, Palmblad U (eds) Levande skärgårdsnatur 2010-med rapporter från 2007. Skärgårdsstiftelsen, Stockholm

Staunton Smith J, Johnson CR (1995) Nutrient inputs from seabirds and humans on a populated coral cay. Mar Ecol Prog Ser 124:189-200 
Takamura N, Iwakuma T (1991) Nitrogen uptake and C-N-O ratio of epiphytic algae in the littoral zone of Lake Kasumigaura. Arch Hydrob 121:161-170

Tilman D (1982) Resource competition and community structure. Princeton University Press, Princeton, NJ

Towns DR, Wardle DA, Mulder CPH, Yeates GW and others (2009) Predation of seabirds by invasive rats: multiple indirect consequences for invertebrate communities. Oikos 118:420-430

Vander Zanden MJ, Rasmussen JB (1999) Primary consumer delta $\mathrm{C}-13$ and delta $\mathrm{N}-15$ and the trophic position of aquatic consumers. Ecology 80:1395-1404

Vanderklift MA, Ponsard S (2003) Sources of variation in consumer-diet delta N-15 enrichment: a meta-analysis. Oecologia 136:169-182

> Voss M, Deutsch B, Elmgren R, Humborg C and others (2006) Source identification of nitrate by means of isotopic tracers in the Baltic Sea catchment. Biogeosciences 3:663-676

Wainright SC, Haney JC, Kerr C, Golovkin AN, Flint MV (1998) Utilization of nitrogen derived from seabird guano by terrestrial and marine plants at St. Paul, Pribilof Islands, Bering Sea, Alaska. Mar Biol 131:63-71

Wikstrom SA, Kautsky L (2007) Structure and diversity of invertebrate communities in the presence and absence of

Editorial responsibility: Steven Morgan,

Bodega Bay, California, USA canopy-forming Fucus vesiculosus in the Baltic Sea. Estuar Coast Shelf Sci 72:168-176

Wootton JT (1991) Direct and indirect effects of nutrients on intertidal community structure-variable consequences of seabird guano. J Exp Mar Biol Ecol 151:139-153

Wootton JT (1992). Indirect effects, prey susceptibility, and habitat selection-impacts of birds on limpets and algae. Ecology 73:981-991

> Worm B, Sommer U (2000) Rapid direct and indirect effects of a single nutrient pulse in a seaweed-epiphyte-grazer system. Mar Ecol Prog Ser 202:283-288

Worm B, Lotze HK, Sommer U (2000) Coastal food web structure, carbon storage, and nitrogen retention regulated by consumer pressure and nutrient loading. Limnol Oceanogr 45:339-349

Young HS, Hurrey L, Kolb GS (2011) Effects of seabirdderived nutrients on aquatic systems. In: Mulder $\mathrm{CPH}$, Anderson WB, Towns DR (eds) Seabird islands: ecology, invasion, and restoration. Oxford University Press, Oxford

Zelickman EA, Golovkin AN (1972) Composition, structure and productivity of neritic plankton communities near the bird colonies of the northern shores of Novaya Zemlya. Mar Biol 17:265-274

Submitted: February 4, 2010; Accepted: July 20, 2010

Proofs received from author(s): October 14, 2010 